\title{
Mass customisation and IT influence on Brazilian health industries' competitiveness
}

\author{
Heitor Luiz Murat de Meirelles Quintella and \\ Jaci Tadeu O. Carvalho*
}

Department of Production Engineering

Universidade Federal Fluminense (UFF)

Rua Passo da Pátria, 156, Sala 309

São Domingos, Niterói - RJ - CEP: 24.210-240, Brazil

E-mail: hquintel@unisys.com.br

E-mail: jaci.tadeu@gmail.com

*Corresponding author

\begin{abstract}
This article analyses the competitiveness of Brazilian medical products and pharmaceutical industries based on the strategic implementation of Information Technology (IT). The model of competitiveness developed by Boynton et al. (1993) - Dynamic Stability and the assessment of IT presence in Porter and Millar's (1985) Value Chain - are the theoretical references of this study. A field research was carried out simultaneously at the Marketing and IT departments of 14 Brazilian plants. Its main goals were to assess how those plants are reacting to the change of the competition pattern, to identify the customisation usage as a competitive differential, and last but not least, to ensure an intensified flow of computer resources. A comparative analysis of data obtained in different field research done in the USA and Brazil also illustrates the viewpoints.
\end{abstract}

Keywords: mass customisation; dynamic stabilisation; Information Technology; IT; product-process engineering; strategic alignment; Brazil; health industries.

Reference to this paper should be made as follows: Quintella, H.M. and Carvalho, J.T.O. (2007) 'Mass customisation and IT influence on Brazilian health industries' competitiveness', Int. J. Mass Customisation, Vol. 2, Nos. 1/2, pp.128-138.

Biographical notes: Heitor M. Quintella, PhD in Systems Engineering, has been lecturing and doing research in Brazil and the UK for the past 35 years. He worked for the IBM Scientific Center and IBM Consulting Group. He was one of the founders of Business Transformation Cells in Latin America and co-author of IBM methodologies. As a Director of Moddata, he led an R\&D Centre with sites in the USA and Brazil. He was Assistant to the Presidency of the Republic of Brazil. He is currently at the Universidade Federal Fluminense (UFF), supervising MSc and DSc students, and leading two projects: 'Human and Technological Factors of Competitiveness' (HTFC) and 'Program for the Integration of Enterprise with Universities' (PIEU). He was President of Stratimidia Consulting, which has consortium ventures with Booz Allen and Hamilton, Giga Advisory (Gartner) and Questera (A Forrester Research Partner). 


\begin{abstract}
Jaci Tadeu O. Carvalho earned his Masters Degree in Production Engineering from Universidade Federal Fluminense (UFF) in 2001. He is currently an Independent Consultant in Strategic Marketing and Strategic Management, Executive Coordinator of ALUMNI COPPEAD - Graduate School of Business of the Federal University of Rio de Janeiro (UFRJ) and Strategic Management Professor at LATEC/UFF. He was B.Braun Executive at the date of submission, where he was awarded with the National Confederation of Industry (CNI) prize 'Design Management', in 1999. Carvalho has published papers in several Brazilian magazines and congresses, including ANPAD - The National Association of Post-Graduate Studies and Research in Administration. His research interests are in mass customisation, product development, marketing and strategic management. Carvalho is also Research Associate and person point of mass customisation in the project 'Human and Technological Factors of Competitiveness' (HTFC) at UFF.
\end{abstract}

\title{
1 Introduction
}

The Brazilian domestic companies or even the multinational companies in operation for more than a decade have never been through such an intense competitive scenario as they have today. After the opening of the Brazilian market towards imported products, new references for pricing and quality have been imposed, triggering revolutions in its domestic market, as well as in its productive environment. In the 1990s, besides the productive context, the so-called economic blocks also defined several commercial changes, such as the MERCOSUL (Southern Common Market) in South America.

Although Brazil is increasing the modernisation level of its industries in the health segment, it still occupies a mediocre 125th place in the world ranking among the 191 researched countries, according to the World Health System 2000 Report of the World Health Organization (WHO).

There are several reports on the Brazilian population's difficulty in accessing the health system, caused by an inefficient system, by the low educational level of its population and by the uneven income distribution that leads to misery.

\footnotetext{
"Brazil currently has only $26 \%$ of its population assisted by private health systems and insurance. 77\% depend on SUS $^{1}$ - Sistema Único de Saúde (Brazilian Health System) and 7\% (12 million people) have no access at all to any kind of Medical assistance whatsoever."2
}

The research 'The northeastern drought 98-99: from the economic crisis to a social calamity' (Duarte, 1999), reveals the situation of Brazilian people from the northeast. They have a monthly per capita income of nearly a fifth of \$R80 (\$US35) which, according to the Getulio Vargas Foundation (FGV), leaves 50 million Brazilians in a state of misery.

On the other hand, one can also find reports in media on a strong activity of the Ministry of Health that has been improving and restructuring, in a systemic and planned way, the Brazilian health system, through several resolutions issued by the Agência Nacional de Vigilância Sanitária (ANVISA, the Brazilian Sanitary Bureau) of the Ministry of Health. Brazil is also achieving international recognition for specific projects and results, such as the Drug Distribution System for HIV and organ transplants (Brazil 
ranked second, behind the USA, in numbers of organ transplants - approximately 10000 a year), as well as for having the second-largest private healthcare market after the USA (Estatística de Saúde - AMS, 2002).

As the Brazilian medical products and pharmaceutical industries play an important role in hospital activity, they have an important role in the ongoing improvement of the quality of life of the Brazilian population. Having competitive industries in this segment means distributing in a more democratic fashion, more quality services at a lower cost and mainly establishing a reference for developing countries.

This paper shows results of the competitiveness analysis of these industries based on the positioning of their products and the use of Information Technology (IT).

Based on the models of Dynamic Stability by Pine (1994) and the value chain by Porter and Millar (1985), a field research was carried out jointly with IT and marketing executives from 14 plants. Its main goals were to assess how those plants were reacting to change competition patterns, to ensure the intensified flow of computer resources and to identify mass customisation as a leading edge.

\section{Sample identification and segmentation}

The sample was gathered into two main groups - medical equipment and products industries, and pharmaceutical industries. The chosen companies met the leading criteria in these segments. Official support, specially for the medical equipment and products, was provided by Associação Brasileira da Indústria de Artigos e Equipamentos Médicos, Odontológicos, Hospitalares e de Laboratório (ABIMO - Brazilian Health Industries Association), ${ }^{3}$ which pointed out the most representative and opinion-making companies in this segment.

Out of the 37 companies invited, only 17 business units from 14 different companies took part in the research. Although $38 \%$ is considered to be a good participation rate, it clearly shows a still insignificant participation of Brazilian companies in academic research.

Thus, the following companies participated in the research: 3M, B.Braun, BD-Becton Dickson, Cremer, Darrow, DMG, Edwards Lifescience, ${ }^{4}$ Glaxo, ${ }^{5}$ Instituto Vital Brasil, Knoll, Merck, Sanofi, Smithkline 5 and Takaoka.

\section{Perception of the new competitive scenario}

The market turbulence, defined by Pine (1994) as being a generalised change phenomenon in the business environment striking markets, products and processes, was assessed through marketing executives.

In a general way, a strong perception of turbulence, mainly due to the market opening in the early 1990s was identified, which has influenced businesses till the present date. A more detailed analysis on the change phenomenon in the country points out factors such as technological changes, competition intensity and the change of customer needs.

The result of this research was compared to that performed by Pine (1994) in the USA on the assessment of perception on market changes between 1980 and 1991. They are shown in Figure 1. 
Figure 1 Histogram of the change in market turbulence perception
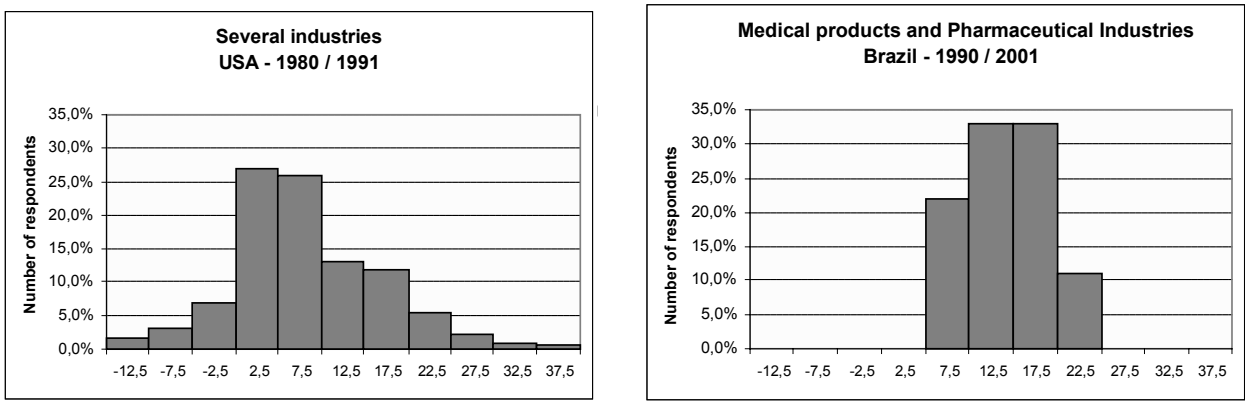

Despite the application of questionnaires in different decades, we can verify that executives from Brazilian medical products and pharmaceutical industries experienced a greater change comparing with their US peers. The group with larger market concentration lies between 10 and 20 (change values); while in the US market, it is situated between 0 and 10 .

US industries point out the competition intensity as the main factor, followed by customer needs and quality influence. The factor of quality influence, on the average, reached a low ranking in the Brazilian industries. This can be explained by the intense regulation in the sector through issues such as Good Manufacturing Practice (GMP) and requirements of the Ministry of Health. Factors such as 'buyer power', 'economic cycles' and 'products life cycles', despite having got different rankings, had very close average values that denote the influence of market globalisation.

\section{Analysis of IT usage to face competitors}

IT has achieved strategic importance and is the most intensively used tool in business. Besides participating in all activity chains in the company, it has been altering the competition scope, as well as continuously reformulating the way through which products and services meet customers' needs.

Through the analysis of IT from a strategic and operational view, this paper assesses the strategic positioning of the companies researched.

The following set of strategic objectives linked to specific use of information instruments, proposed by Porter and Millar (1985), were analysed during the research:

- $\quad$ create barriers to entry (entrance)

- generate cost for customer change supplier (change cost)

- differentiate product or service offered by the company (differentiation)

- create new businesses or products

- change the value chain

- cost reduction

- $\quad$ change relationship with purchasers and/or suppliers (relationship). 
Through the analysis of the degree of average utilisation of IT instruments (tools) shown in Figure 2, we can assume that there is a large, yet introverted utilisation of IT resources in strategic objectives in medical equipment/goods industry. The major differences are found in the transformation of the value chain, giving emphasis on process and products and on the making of entrance barriers in an isolated form.

Figure 2 IT use related to strategic objectives - comparison between two industry segments

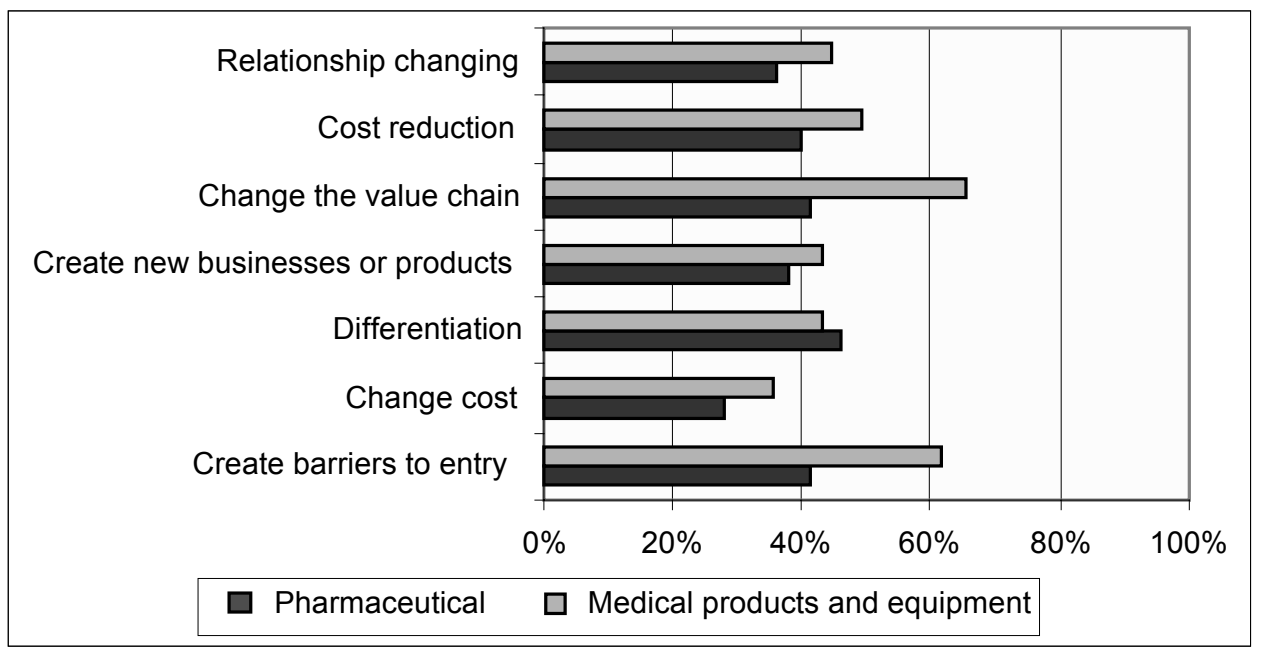

We can also assume that the utilisation of IT resources in the pharmaceutical industry segment is weak, with all the items below $45 \%$. This means that the pharmaceutical industry makes uses of IT resources in a non-integrated and badly distributed way.

\section{Analysis on the utilisation of computer resources}

Besides the analysis on strategic objectives, the application of current resources in information systems was assessed, as well as the perception of the benefits obtained through the implementation of Computer Integrated Manufacturing (CIM) and the Computer Integrated Enterprise (CIE).

The utilisation of information systems, either in the pharmaceutical industry or in the medical products and equipment segment, is strongly concentrated on office automation and support to managerial decision, with rates from $75 \%$ and higher.

Therefore, the utilisation of computer resources is still related to internal activities - revealing a strongly introverted vision.

For the application of CIM and CIE, a comparative analysis was carried out jointly with the research on the application of IT by FGV (Quintella and Costa, 1997) and is presented in Figure 3. It was called Amostra Brasil I (Sample Brazil I). In this research, FGV assessed, under the same focus, the leading companies and the opinion makers on the use of IT. 
Figure 3 Use of information resources - introverted versus extroverted strategic vision
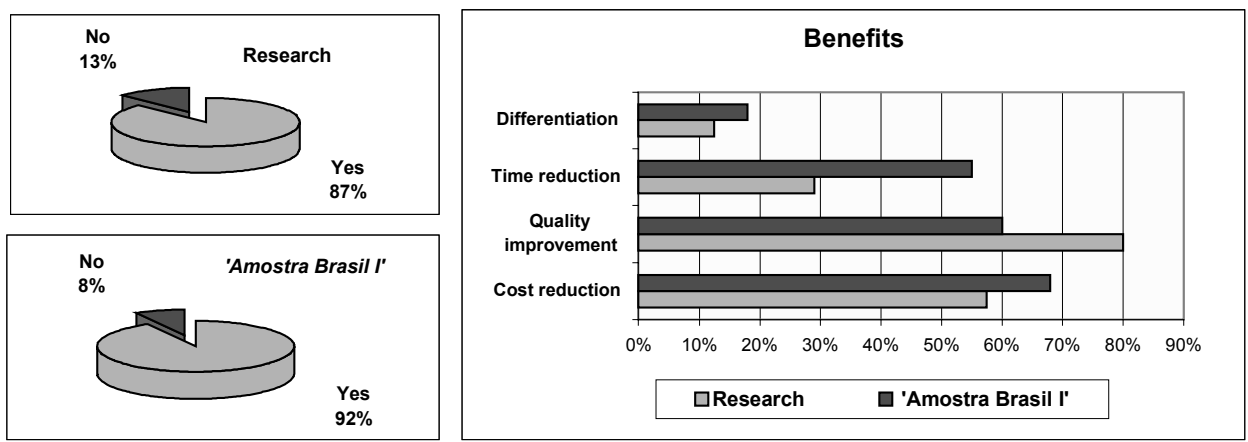

The answers to the IT query show that $87 \%$ of the companies sampled are heading towards computerised integration in their production processes.

The results of the CIM evaluation confirm the introverted trend of their benefits. Its use is driven towards internal improvements rather than the differentiation of their products and services. It can also be stated that the use of CIM in the medical products industry is even weaker for the extroverted viewpoint than the companies from Amostra Brasil I.

The perception of objectives reached by CIE and CIM confirms the strong introversion of the sampled companies. Consistently with the turbulence results and very adherent to the Amostra Brasil I results, the differentiation was not appointed as a strong motivating factor in the computer integration process.

As shown in Figure 4, a strong introversion of the companies researched was identified through an inference analysis on introversion versus the external vision of IT use. We assume that there is a trend towards an equilibrium in IT strategic objectives. The utilisation of computer resources and the benefits of CIM and CIE confirm this introversion.

Figure 4 CIM benefits - introverted versus extroverted strategic vision

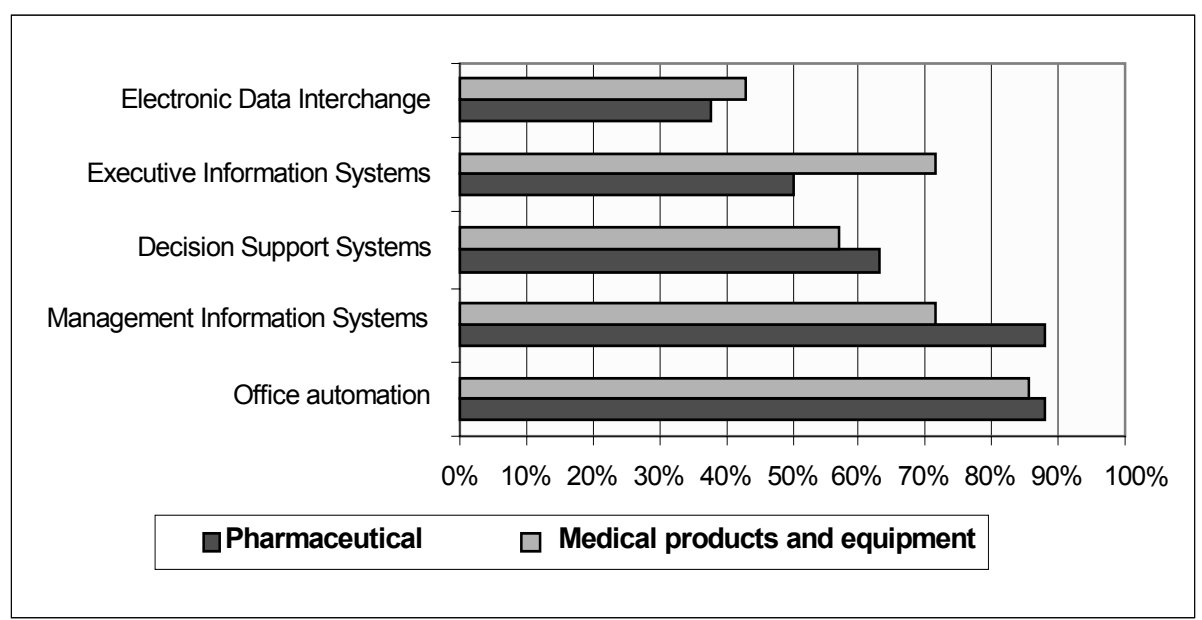




\section{Correlation between Dynamic Stability and Value Chain models}

It is possible to identify the positioning of a company in one of the quadrants of the Dynamic Stability model (Pine, 1994) through the analysis of its 'value chain', in case there is consistency in the strategy for positioning of products and processes and the use of IT. There is a direct correlation among the features of each quadrant defined by Pine (1994) and the mode and intensity of the utilisation of IT described by Porter and Millar (1985).

In Figure 5, we can see the quadrants of the Dynamic Stability model in the respective categories of the 'activity chain' of the Value Chain model.

Figure 5 Correlation between Dynamic Stability and Value Chain models

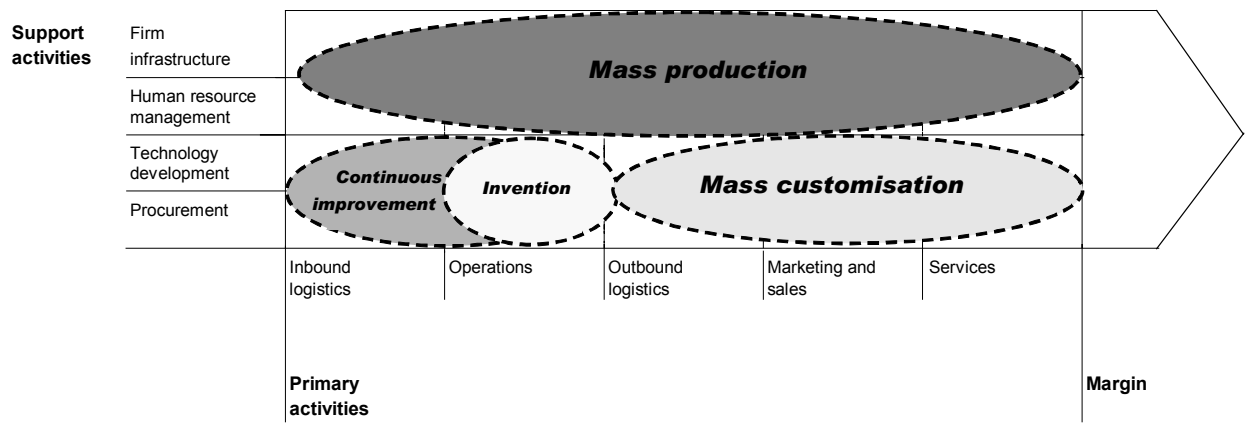

The companies within the 'mass production' quadrant are using IT more intensively in the upper end of the Value Chain model. In this area, the support activities are more concentrated on the 'infrastructure' and 'human resources management' categories, permeating the whole primary activities category. Such positioning is justified by the great standardisation potential of tasks owing to the stabilisation of product and process and the foreseeing of demands.

The companies found in the 'invention' quadrant use IT more intensively for developing technology and for flexibility and optimisation of processes aiming at supporting the making of new products on a small scale. Therefore, they are placed in the Value Chain model in the 'operations' category supported by 'technology development' and 'procurement' categories.

The companies found in the 'continuous improvement' quadrant search for competitive advantage by improving operational performance. Therefore, IT is intensively used in the 'inbound logistics' and 'operations' categories of the primary activities supported by the 'technology development' and 'procurement' categories of support activities.

Finally, in the companies that are in the 'mass customisation' quadrant, IT is intensively used in the 'outbound logistics', 'marketing and sales' and 'services' categories, and also supported by 'technology development' and 'procurement' categories. That is justified by the need for efficiently meeting the needs and desires of their customers. 


\section{Analysis on the strategic consistency of IT use with the positioning of products and processes}

According to Ferraz et al. (1997), competitiveness is the ability of a corporation to formulate and implement competitive strategies that allow it to keep or even to enlarge a sustainable market position in the long run. As reported by Porter (1996), strategy involves creating 'fit' among a company's activities, interacting and reinforcing one another.

The research promoted the assessment of the strategic consistency between IT application and the ranking of products and processes of the companies researched.

Supported by the stability model suggested by Pine (1994), the companies that belong to the pharmaceutical industry segment were placed in the 'continuous improvement' quadrant and the ones belonging to medical equipment and products were placed in the 'continuous improvement' quadrant and/or 'mass customisation'. Through the survey on specific objectives on the use of IT appointed by Porter (1996), it was possible to analyse the placement consistency of their products.

\section{Heading towards mass customisation}

The mass customisation analysis was assessed only in the medical products and equipment segment, according to its placement in Pine's (1994) model.

Through the analysis of products and processes placement, customisation was identified. Eighty-five percent of the businesses units researched were customising their products and services, aiming at more specific medical procedures. Within this group, half of it had reached a customisation level above 50\%.

The executives who participated in the research agreed with each other's points of view as far as the importance of mass customisation was concerned. The growth trend and its competitive advantage were recorded. The appointed mass customisation limit was the cost of the economic batch versus customers' specific needs.

That reveals a movement towards modernisation and the new competitive frontier in business competition mentioned by Pine (1994).

\section{Conclusion}

This paper shows that the researched industries perceive the market turbulence and that they have strategic consistency regarding IT use with the placement of their products and services. It should be highlighted that, as in the Amostra Brasil I (Quintella and Costa, 1997), this paper did not mean to perform a thorough analysis of the researched industries, but to identify their executives' perception of the use of IT as a competitive lever.

The identification of the use of products/services customisation and the reckoning of some executives that customisation is a competitive differential prove that is emerging a mature relationship with the market, and, somehow, pro-active movements towards modernity. Therefore, it is well-adapted to changes in the new global competition. 
The analysis ${ }^{6}$ of IT usage, the perception of IT executives on the benefits of the integration of the manufacturing area - CIM - and the company integration - CIE - still show a strong introversion as opposed to a major interaction with the market. This is a very interesting and specific approach for the Brazilian industries belonging to the segment analysed, therefore requiring specific analysis. IT usage is a tool for responsiveness to new laws and regulations that control the industries. We cannot, therefore, say that these industries totally lack extroverted vision or objectives.

On the contrary, the health segment, besides being industrially involved in the global competitive context, is going through a major reformulation of its structure. It has been intensively broadcasted by the press and officially identified by the normative resolutions issued by the ANVISA, necessitating adjustments and modifying the new competition scenarios.

One of the major examples on this aspect is caused by 'generic medicine' and takes place in the segment of pharmaceutical industries'. The Government's action alters the systemic determinant stated by Ferraz et al. (1997), besides attractiveness determinant stated by Porter (1996): new entrant's threat.

Another very significant point on the analysis of strategic consistency was the identification of at least one company working on IT to support an organisational architecture for different conditions of products and processes, exploiting, therefore, the best benefits of mass customisation. The basis of this competition basis is determined by Pine (1994) to be the Dynamic Stability and is considered at least as the competition strategy of this century.

\section{Acknowledgement}

The authors are grateful for the recommendations and suggestions made by the referees that substantially enhanced the present article.

\section{References}

Boynton, A.C., Victor, B. and Pine, B.J. (1993) 'New competitive strategies: challenges to organizations and information technology', IBM System Journal, Armonk, Vol. 32, No. 1, pp.40-64.

Duarte, R.S. (1999) A seca nordestina de 1998-1999: Da crise econômica para a calamidade social (The Northeastern Drought 98-99: From the Economic Crisis to a Social Calamity), Recife: SUDENE/Fundação Joaquim Nabuco.

Estatística de Saúde - AMS (2002) Health Ministry Statistics - AMS 2002 Press Release, http://www.ibge.gov.br/ home/estatistica/populacao/condicaodevida/ams/ (captured on 21 December 2001).

Ferraz, J.C., Kupfer, D. and Haguenauer, L. (1997) Made in Brazil: Desafios competitivos para a indústria (Made in Brazil: Competitive Challenges to the Industries), Rio de Janeiro: Campus.

Pine, B.J. (1994) Personalizando Produtos e Serviços - Customização maciça: A Nova Fronteira da Competição dos Negócios. (Mass Customization - The New Frontier in Business Competition), Veiga, E.E.O. (Trans.), H.M. Quintella (technical revision), São Paulo: Makron Books.

Porter, E.M. (1996) 'What is strategy?', Harvard Business Review, November-December. 
Porter, M.E. and Millar, V.E. (1985) 'How information gives you competitive advantage', Harvard Business Review, July-August.

Quintella, H.M. and Costa, S.G. (1997) A informática e a mudança do paradigma competitivo (Information Technology and Competitiveness Paradigm Changing), Rio de Janeiro: Conjuntura Econômica, March, pp.34-38.

\section{Notes}

1 Brazilian Government Health System to support low-income people

2 Marketing Director of Glaxo do Brasil S/A - during his lecture in Laboratórios B.Braun S/A on 12th April 2001. The last official Brazilian press report about this issue was released in 1998: Acesso e Utilização de Serviços de Saúde - 1998/ IBGE (Access and usage of Health Services/IBGE - Brazilian Institute of Geography and Statistics), which reveals that only $71.2 \%$ of the Brazilian population had regular health assistance.

3 ABIMO has officially support for this study.

4 At the field research time, Edwards Lifescience was an integrant of Baxter Group.

5 The field survey was performed before the fusion of Glaxo \& Smithkline fusion.

6 Other publications consulted to develop this study:

- Alves-Mazzoti, A.J. and Gewandsznanjder, F. (1999) O Método nas Ciências Naturais e Sociais: Pesquisa Quantitativa e Qualitativa (Social and Natural Scientific Method: Qualitative and Quantitative Research), 2nd ed., São Paulo: Pioneira, p.203.

- Blau, P.M. and Schoenherr, P.A. (1971) The Structure of Organizations, New York: Basic Books, Inc., 455pp.

- Davis, S.M. (1987) Future Perfect, New York: Addison-Wesley Publishing Co., Reading.

- Drucker, P.F. (1995) Administrando em Tempos de Grandes Mudanças (Managing in a Time of Great Change), N. Montingelli Jr. (translator), L. Guazzelli (technical review) São Paulo: Pioneira, 234pp.

- Eco, U. (1998) Como se faz uma tese (How to Prepare a Thesis), G.C. Cardoso de Souza (translator), P.M. Filho (technical review), 14th ed., São Paulo: Perspectivas, 174pp., Translation of: Como se fa una tesi di laurea.

- Esty, D.C. and Porter, E.M. (2000) Measuring National Environment Performance and Its Determinants, Yale University School of Law and Yale School of Forestry and Environmental Studies, Harvard Business School.

- Gilmore, J.H. and Pine, B.J. (2000) Markets of One: Creating Customer-Unique Value through Mass Customisation, Boston: Harvard Business School, 210pp.

- Junior, A.D.C. (1962) Strategy and Structure: Chapters in the History of the American Industrial Enterprise, Cambridge: The MIT Press.

- Kanitz, S. (1995) O Brasil que dá certo - O Novo Ciclo de Crescimento 1995-2005 (Brazil - The Emerging Economic Boom 1995-2005), São Paulo: McGraw-Hill, 102pp.

- Lakatos, E.M. and Marconi, M.A. (1992) Metodologia Científica (Scientific Methodology), 2nd ed., São Paulo: Atlas, 250pp.

- McKenney, J.L. and McFarlan, F.W. (1982) 'The information archipelago - maps and bridges', Harvard Business Review, September-October, p.109.

- Nonaka, I. (1991) 'The knowledge creating company', Harvard Business Review, December, Vol. 69, No. 6, pp.96-104.

- Parson, G.L. (1983) 'Information technology: a new competitive weapon', Sloan Management Review, September-November, p.3. 
- Pine, B.J. (1993) Mass Customization: The New Frontier in Business Competition, Boston: Harvard Business School, 330pp.

- Piore, M.J. and Sabel, C.F. (1984) The Second Industrial Divide: Possibilities for Prosperity, Nova Iorque: Basic Books.

- Popper, K.S. (1975) A lógica da Pesquisa Científica (The logic of Scientific Research), 2nd ed., São Paulo: Cultrix.

- Porter, M.E. (1979) 'How competitive forces shape strategy', Harvard Business Review, March-April.

- Porter, M.E. (1999) 'Measuring the microeconomic foundations of prosperity', Harvard Business Review. 